\title{
RESPONS PETANI TERHADAP INOVASI BUDIDAYA DAN PEMANFAATAN SORGUM DI KECAMATAN SRANDAKAN KABUPATEN BANTUL
}

\section{Farmer Response to Innovation in Cultivation and Use of Sorghum in Srandakan Sub District Bantul Regency}

\author{
Alvitri Wijayanti ${ }^{1}$, Subejo $^{1}$, Harsoyo $^{1}$ \\ ${ }^{1}$ Penyuluhan dan Komunikasi Pertanian
}

\begin{abstract}
This research was conducted in Poncosari Village, Srandakan Sub District, Bantul Regency. Poncosari Village is an area that farmers cultivate sorghum. This research aims to determine the innovation cultivation and utilization of sorghum, the response of farmers to the innovation and utilization of sorghum and use the products for varrous purposive, and the factors that influence the response of farmers on cultivation innovation and they use of sorghum product in Srandakan Sub District, Bantul Regency. The research results showed that the response rate of cultivate innovation of sorghum farmers and utilization was $57.99 \%$. Where $90 \%$ of the farmers are still hesitant to application innovation and utilization of sorghum cultivation. The eason that sorghum is a newdeveloped technology in the surveyed area. Perception and motivation in a positively and significantly influence to the response off armerson cultivation innovation and utilization of sorghum cultivation. Factors that did not significantly influence to the response on farmers cultivating innovation and utilization of sorghum areage, education, land lize, sorghum farming experience, and intensity extension activity.
\end{abstract}

Keywords: Response attitude, behavioral responses, innovation and utilization of sorghum cultivation, Bantul.

\section{INTISARI}

Penelitian ini dilakukan di Desa Poncosari Kecamatan Srandakan Kabupaten Bantul. Desa Poncosari merupakan wilayah yang menerapkan sorgum mulai dari budidaya sampai pemanfaatan menjadi produk lain. Penelitian ini bertujuan untuk mengetahui inovasi budidaya dan pemanfaatan sorgum, respons dari petani terhadap adanya inovasi budidaya dan pemanfaatan sorgum, dan faktor-faktor yang mempengaruhi respons petani terhadap inovasi budidaya dan pemnafaatan orgum di Kecamatan Srandakan Kabupaten Bantul. Hasil penelitian menunjukkan bahwa tingkat respons petani terhdap inovasi budidaya dan pemanfaatan sorgum sebesar $57,99 \%$. Dimana $90 \%$ petani masih ragu-ragu terhadap penerapan inovasi budidaya dan pemanfaatan sorgum. Hal ini dikarenakan sorgum merupakan teknologi baru yang dikembangkan. Persepsi dan motivasi berpengaruh nyata secara positif terhadap respons petani terhdap inovasi budidaya dan pemanfaatan sorgum. Faktor -faktor yang tidak berpengaruh nyata terhadap respons petani terhdap inovasi budidaya dan pemanfaatan sorgum adalah umur, tingkat pendidikan, luas lahan, pengalaman usaha tani sorgum, dan intensitas mengikuti penyuluhan.

Kata kunci: Respons sikap, respons perilaku, inovasi budidaya dan pemanfaatan sorgum, Bantul.

\section{PENDAHULUAN}

Pembangunan di bidang tanaman pangan dan holtikultura yang diarahkan untuk mewujudkan pertanian yang maju, efisien, dan tangguh merupakan bagian yang integral dari pembangunan nasional. Dalam pelaksanaan pembangunan tersebut dirancang suatu proses transformasi struktur sektor pertanian denga memanfaatkan sumber daya alam, sumber daya manusia, modal, iptek serta manajemen modern.

Perubahan struktur sektor pertanian direflesikan oleh perubahan-perubahannya dalam proses pengelolaan sumber daya ekonomi yang tidak lagi hanya berorientasi kepada upaya peningkatan produksi tetapi juga kepada upaya peningkatan pendapatan dan kesejahteraan masyarakat (Wibowo, 2000).

Salah satu yang erat kaitannya dengan sektor pertanian adalah komoditi pertanian. Komoditi pertanian adalah barang produksi yang dihasilkan dari sektor pertanian. Komoditi pangan merupakan komoditi yang terus dihasilkan oleh sektor pertanian dan digunakan oleh 
konsumen sehingga perlu adanya pengamanan komoditi pangan. Keamanan komoditi pangan turut mendukung program pemerintah dalam mengatasi kerawanan pangan.

Pemerintah mengeluarkan program untuk mengatasi masalah kerawanan pangan yaitu dengan penganekaragaman pangan. Dengan program tersebut diharapkan masyarakat tidak hanya mengandalkan beras tetapi dapat memanfaatkan bahan pangan lain yang dapat menggantikan beras namun tetap memiliki nilai gizi yang setara dengan beras. Penganekaragaman pangan dilakukan dengan memanfaatkan komoditi pangan yang ada seperti contohya umbi-umbian, singkong (Manihot Esculenta), Ubi jalar (Ipomea Batatas L.), talas (Colosia Esculenta (L.) Schott), dan Sorgum (Sorghum bicolor L.). Selain itu, pada beberapa tahun terakhir pemerintah juga membuat program tentang optimalisasi lahan pertanian untuk budidaya tanaman sorgum guna mempromosikan program ketahanan pangan nasional.

Sorgum merupakan salah satu komoditi pangan yang belum banyak dibudidayakan di Indonesia karena jenisnya yang langka. Namun sebenarnya membudidayakan tanaman ini bukan hal yang sulit karena secara teknis budidaya tanaman ini tidak jauh berbeda dengan budidaya tanaman jagung. Sorgum menjadi salah satu tanaman pangan yang telah sukses dikembangkan di dunia terutama negara-negara maju seperti Amerika sehingga memiliki nilai jual yang tinggi. Sedangkan di Indonesia, sorgum berada pada tahap pengenalan dan pengembangan. Dengan demikian sorgum menjadi suatu inovasi untuk dunia pertanian di Indonesia. Sorgum sebagai suatu inovasi menambah keanekaragaman tanaman pangan yang sekaligus dapat mengurangi impor. Sorgum dapat dibudidayakan di lahan marjinal sebagai upaya optimalisasi lahan kritis yang kurang termanfaatkan. Hal ini dikarenakan sifat tanaman yang secara teknis budidaya mudah, tidak membutuhkan banyak air, dan dapat dikembangkan secara optimal hasilnya. Hal merupakan sebuah inovasi yang sekaligus dapat memanfaatkan lahan.

Salah satu wilayah yang memiliki lahan marjinal yang berpotensial untuk ditanami tanaman sorgum adalah Kabupaten Bantul. Selain itu di wilayah ini terdapat banyak lahan kritis yang tidak termanfaatkan sehingga dapat berpotensi sebagai media tanam sorgum.
Budidaya sorgum di Kabupaten Bantul sudah dilakukan sejak tahun 2011. Salah satu Kecamatan yang menjadi sentra pengembangan sorgum di Kabupaten Bantul adalah Kecamatan Srandakan. Inovasi budidaya tanaman sorgum disosialisasikan oleh Dinas Pertanian dan BPP kepada petani melalui penyuluhan. Selama dua tahun budidaya sorgum berjalan dengan baik, petani memiliki ketertarikan terhadap budidaya sorgum. Respons petani terhadap budidaya tanaman sorgum menjadi hal penting dalam menentukan perilaku petani sebagai pelaku utama yang akhirnya menentukan keberlanjutan kegiatan. Respons yang beragam dari petani nantinya akan menentukan apakah teknologi ini akan bertahan lama atau tidak.

\section{TINJAUAN PUSTAKA}

\section{Budidaya Sorgum}

Kelebihan sorgum dibandingkan dengan tanaman serealia lainnya adalah ketahanannya terhadap kekeringan. Tahan kering ini disebabkan oleh adanya lapisan lilin pada batang dan daunnya serta permukaan daun yang relatif kecil yang dapat mengurangi kehilangan air karena penguapan. Kelebihan lain dari tanaman sorgum yaitu dapat dipangkas (diratoon) sampai beberapa kali dan hasil ratoonnya dapat menyamai atau bahkan lebih dari hasil tanaman induknya (Ismail dan Kodir, 1977).

Sorgum dapat tumbuh pada suhu optimum untuk pertumbuhan yaitu berkisar antara $23^{\circ}$ $30^{\circ} \mathrm{C}$ dengan kelembapan relatif $20 \%-40 \%$. Pada daerah-daerah yang tingginya lebih dari 800 meter dari permukaan laut dimana suhunya kurang dari $20^{\circ}$ tanaman akan terhambat pertumbuhannya dan umurnya menjadi panjang. Curah hujan yang diperlukan selama pertumbuhan antara $375-$ $425 \mathrm{~mm}$ dan distribusinya teratur. Sorgum dapat tumbuh baik pada hampir setiap jenis tanah. Pada umumnya sorgum akan berhasil baik pada tanahtanah ringan. Kemasaman tanah $(\mathrm{pH})$ yang baik untuk pertumbuhan sorgum terletak di antara 5,0 $-7,5$. Sorgum kurang baik tumbuh dengan jenis tanah alkalis. Tanaman sorgum berdaya besar untuk meyerap air tanah (Ismail dan Kodir, 1977).

\section{Pengolahan tanah}

Pengolahan tanah untuk sorgum sebaiknya sama dengan jagung, yaitu dibajak 1-2 kali, digaru kemudian diratakan. Pada waktu penanaman sebaiknya tanah bersih dari tumbuhan pengganggu. Pertumbuhan 
sorgum lambat pada permulsannya, sehingga tidak dapat menyaingi tumbuhan pengganggu dengan baik sampai umur 3-4 minggu. Dengan demikian penanaman sebaiknya segera dilakukan setelah pengerjaan tanah terkahir selesai dilakukan. Drainase juga perlu diperhatikan dengan pembuatan saluransaluran pembuangan terutama pada tanah-tanah berat (Ismail dan Kodir, 1977).

\section{Jarak Tanam}

Penanaman sorgum sebaiknya diatur jarak tanamnya sehingga populasinya berkisar antara 100.000- 150.000 tanamnya per-hektar.

Jarak tanam yang dianjurkan adalah $75 \times 25$ $\mathrm{cm}$ atau $75 \times 20 \mathrm{~cm}$, masing-masing dengan 2 tanaman per-lubang. Pada waktu tanam sebaiknya benih ditanam 2-3 biji per-lubang. Penjarangan menjadi 2 tanaman per-lubang dilakukan pada umur 2 minggu setelah tanam. Kebutuhan benih per-hektar adalah diantara 8-10 kg. Penyulaman yang diperlukan dapat dilakukan dengan biji atau pemindahan tanaman yang berumur sama dengan cara putaran (Ismail dan Kodir, 1977).

\section{Pemupukan}

Pupuk yang diperlukan untuk tanaman sorgum adalah Nitrogen, yang dapat digunakan sampai 90 $\mathrm{kg} \mathrm{N} / \mathrm{ha}$ atau $2 \mathrm{kw}$ Urea/ha. Penambahan pupuk fosfat yang memberikan kenaikan hasil, dapat diberikan sebanyak $45 \mathrm{~kg}$ P2O5 atau $1 \mathrm{kw}$ TSP/ ha. Pupuk Nitrogen diberikan 2 kali yaitu, sepertiga bagian pada waktu tanam bersama-sama dengan seluruh pupuk $\mathrm{P}$ dan $\mathrm{K}$, duapertiga bagian sisanya diberikan pada umur satu bulan setelah tanam. Cara pemberian pupuk adalah diseret di dalam larikan yang dibuat di kiri dan kanan barisan tanaman sejauh $7 \mathrm{~cm}$ dan sedalam $10 \mathrm{~cm}$. Pemupukan Nitrogen yang kedua dilakukan dengan cara yang sama, hanya jarak dari tanaman kurang lebih $15 \mathrm{~cm}$, sedalam $10 \mathrm{~cm}$ (Ismail dan Kodir, 1977).

Pupuk dapat juga diberikan dalam lubang yang berada di sebelah kiri dan kanan lubang biji, namun cara ini membutuhkan waktu dan tenaga yang lebih banyak. Pemakaian pupuk kandang dapat juga dianjurkan, apalagi apabila penanaman sorgum tersebut ditujukan untuk makanan ternak, dengan demikian hara yang diserap tanaman dapat dikembalikan ke dalam tanah (Ismail dan Kodir, 1977).

\section{Pengairan}

Sorgum merupakan tanaman yang tahan terhadap kekurangan air namun sorgum tetap membutuhkan air untuk hidup. Air yang dibutuhkan oleh tanaman ini antara lain 2 sampai 4 kali pengairan tergantung dari masing- masing jenis tanah. Tempat- tempat yang tidak memiliki sumber pengairan, dapat dibuat sumur karena air dalam tanah tidak dalam (Rismunandar dan Fraeyhoven, 1973).

\section{Pemeliharaan}

Menurut Rismunandar dan Fraeyhoven (1973), pemeliharaan sorgum terdiri dari :

\section{1) Penjarangan tanaman}

Dilakaukan pada tanaman yang sudah mencapai ketinggian $10 \mathrm{~cm}$. Pemeliharaan ini harus dilakukan, karena penanaman untuk tiap-tiap lubang 3-4 biji apabila dibiarkan akan terlalu padat tanamannya. Dengan pengisian 3-4 biji tiap-tiap lubang untuk tiap hektar diperlukan 6-9 kg biji, sedangkan tiap-tiap kg biji sorgum terdiri dari ratarata 14.000-20.000 butir biji.

2) Pembumbunan dan penyiangan

Penyiangan biasanya dikerjakan 2 kali yaitu saat tanaman memiliki rata-rata tinggi 5 $\mathrm{cm}$, dan setelah memiliki rata- rata tinggi 30-40 $\mathrm{cm}$. Penyiangan memiliki tujuan untuk meratakan tanah dan membumbun tanaman. Dengan ini sorgum didorong untuk membentuk akar-akar baru yang keluar dari buku-buku (ruas) bagian atas. Dengan demikian maka dapat bertambah kuat pertumbuhannya. Penyiangan ini baik dilakukan, karena apabila tidak dilakukan dapat mempengaruhi produksi hingga $30-40 \%$.

\section{3) Pengendalian OPT}

Sorgum relatif lebih tahan terhadap hama dan penyakit dibandingkan dengan tanaman palawija lainnya. Dapat dikatakan bahwa sampai saat ini Indonesia belum ada hama atau penyakit penting yang dapat mngekibatkan kerugian besar pada tanmaan sorgum. Beberapa hama penting pada jagung sering juga mnyerang sorgum seperti lalat bibit (Atherigona exigua), ulat daun ( Prodenia litura ). Tindaka pencegahan atau pemberantasan dapat dilakukan dengan penyemprotan memakai 
insektisida seperti surecide, basudin, sevin, dan lain-lain dengan dosis sesuai dengan anjuran (Ismail dan Kodir, 1977).

\section{Pengembangan Sorgum}

Pada periode 2007-2009, penelitian sorgum termasuk dalam program riset insentif terapan Kementrian Negara Riset dan Teknologi. Tujuan penelitian adalah memperbaiki genetik tanaman terkait dengan sifat ketahanan terhadap lahan masam. Penelitian tersebut sangat penting mengingat lebih dari 99,5 juta hektar lahan kering di Indonesia $(69,1 \%)$ merupakan lahan masam (Hidayat et al. cit. Human, 2002).

\section{Respons}

Respons adalah hasil dari perilaku stimulus yaitu aktivitas dari orang yang bersangkutan, tanpa memandang apakah stimulus tersebut dapat diidentifikasikan atau tidak dapat diamati. Respon akan terkait dengan stimulus, sehingga jika stimulusterjadi maka suatu respon akan mengikuti (Gibson et al, 988).

\section{Sikap}

Menurut Triandis (1971) sikap sebagai suatu pendapat disertai perasaan yang menentukan tindakan terhadapsuatu objek. Sedangkan menurut Ajzen, dan Fishben (1970) sikap merupakan suatu kecenderungan untuk secara konsisten memberikan tanggapan menyenangkan atau tidak menyenangkan terhadap suatu objek, kecenderungan ini merupakan hasil belajar, bukan pembawaan.

Menurut Gerungan (1978) ada 3 komponen dalam sikap yaitu :

a. Kognitif adalah sesuatu yang berhubungan dengan akal pikiran. Mencakup pengetahuan, pikiran, kepercayaan yang didasarkan pada informasi.

b. Afektif menunjukkan pada dimensi emosional yaitu dimensi yang berhubungan dengan objek apakah menyenangkan atau tidak menyenangkan.

a. Konatif melibatkan salah satu kredisposisi untuk bertindak terhadap suatu objek. Biasanya menjawab tentang bagaimana kesiapan individu untuk bertindak terhadap suatu objek.

\section{Perilaku}

Van den Ban dan Hawkins (2005) meramalkan perilaku dengan mengukur sikap terhadap perilaku yang sama dan mengingat bahwa perubahan perilaku biasanya membawa akibat yang diinginkan maupun yang tidak diinginkan. Akibat-akibat utama haruslah diukur untuk meramalkan perilaku. Sikap-sikap baru yang didasarkan pada pengalaman responden atau pemikiran sistematis ternyata lebih memungkinkan membawa perubahan perilaku daripada sikap-sikap yang dangkal. Sikap petani lebih besar kemungkinanannya berkaitan dengan perilaku mereka jika mereka jika mereka sudah mencoba sendiri sebuah inovasi atau mengumpulkan informasi mengenainya dari sumber-sumber terpercaya daripada sekedar mendengarkan pembahasan menarik di radio.

\section{Persepsi}

Menurut Umstot cit. Ahmadi (1986) menjelaskan bahwa secara umum persepsi dapat dipandang sebagai proses mengumpulkan, menyeleksi, mengorganisasi, dan menginterpretasikan informasi. Proses tersebut dimulai dari penerimaan informasi dari berbagai indera kemudian di analisis untuk diberi arti. Dengan demikian persepsi adalah suatu proses kognitif yang dialami oleh setiap manusia dalam memahamai informasi lingkungannya, menghasilkan suatu gambaran tentang kenyataan yang dihadapi. Persepsi merupakan unsur penting dalam menyesuiakan perilaku dan lingkungannya. Proses persepsi dapat dilihat pada gambar 2.1.

\section{Motivasi}

Motivasi merupakan sebuah dorongan yang yang muncul dari dalam diri individu untuk melakukan sesuatu. Motivasi akan mendorong seseorang untuk mencapai tujuan yang diinginkan. Hal ini berpengaruh terhadap tingkat keberhasilan seseorang dalam pencapaian prestasi. Dapat dikatakan, seorang individu yang memiliki motivasi yang tinggi akan semakin memiliki dorongan yang kuat dalam melakukan sesuatu yang ingin dicapai sehingga dapat merubah perilaku seseorang untuk terus melakukan apa yang ingin dituju. Weiner (1990), menyatakan motivasi adalah keadaan dalaman sesorang yang membangkitkan, mengarah dan tingkah laku secara berterusan. Menurut 


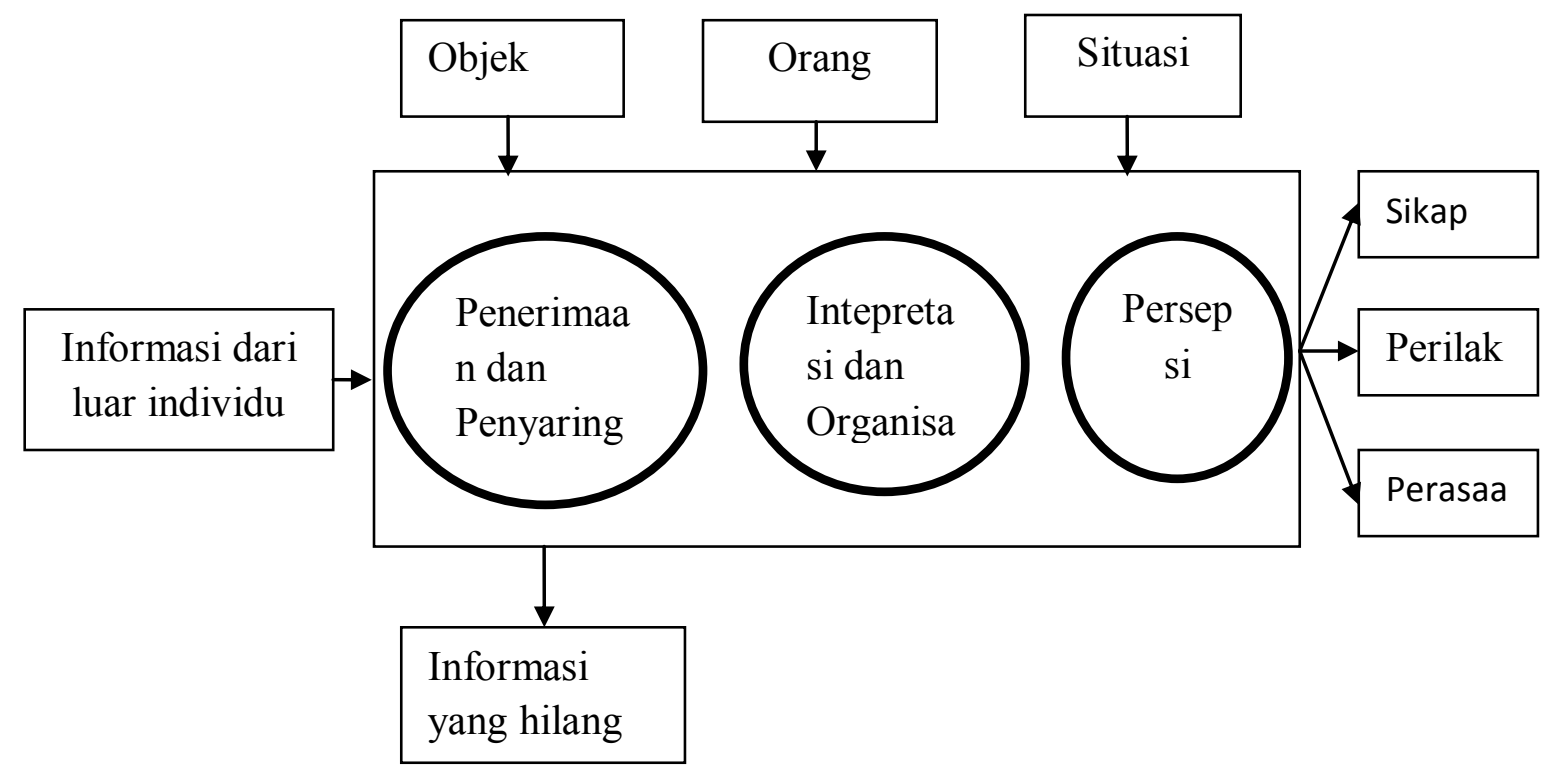

Gambar 2.1. Proses Persepsi Menurut Umstot cit. Ahmadi (1986)

Sudarmo (2000) motivasi adalah faktor-faktor yang ada dalam diri seseorang yang menggerakkan dan mengarahkan seseorang untuk memenuhi tujuan tertentu.

Asmawati (2002), menjelaskan bahawa Teori Maslow ini mengutarakan keperluan keperluan motivasi yang berbeza yang terdapat dalam satu hierarki; dan sebelum keperluan- keperluan yang lebih tinggi diperoleh, keperluan-keperluan primer mestilah dipenuhi terlebih dahulu. Teori ini diterangkan dalam bentuk piramid, di mana keperluan asas terletak di bawah manakala keperluan yang lebih tinggi parasnya terletak di bahagian atas.

\section{METODE PENELITIAN}

\section{Teknik Pengambilan Sampel}

Penelitian ini menggunakan metode deskriptive dengan pendekatan metode kualitatif dan metode kuantitatif secara survei. Penelitian dilakukan di Desa Poncosari Kecamatan Srandakan Kabupaen Bantul secara purposive. Kabupaten Bantul juga sebagai lokasi pelaksanaan program budidaya sorgum dari Kementrian Dirjen Sarana dan Prasarana yang bekerjasama dengan Dinas Pertanian dan Kehutanan divisi Tanaman Pangan Kabupaten Bantul. Pengambilan sampel dilakukan di Desa Poncosari secara purposive dengan asumsi bahwa di Desa tersebut terdapat petani yang membudidayakan sorgum selama dua tahun sejak 2012. Informasi tersebut diperoleh dari Badan
Penyuluhan dan Pertanian Kecamatan Srandakan, dan instansi terkait. Sampel petani yang diambil sebanyak 30 responden dari 60 jumlah anggota Kelompok Tani Bismo. Hal ini dikarenakan hanya terdapat 30 petani yang terlibat langsung dalam budidaya dan pemanfaatan sorgum di Kelompok Tani Bismo sedangkan 30 anggota lainnya hanya memiliki lahan dan digarap oleh petani lainnya. Pengambilan sampel dilakukan dengan metode sensus sebagai obyek penelitian.

\section{Metode Analisis Data}

Analisis data dalam penelitian ini menggunakan beberapa metode pengujian, untuk tujuan yang pertama digunakan metode kualitatif. Metode ini digunakan untuk memberikan penjelasan mendetail, rinci, dan lengkap mengenai topik penelitian.

Pengujian hipotesis yang kedua menggunakan uji proporsi yaitu untuk mnegukur tinggi rendahnya respons petani terhadap inovasi budidaya dan pemanfaatan sorgum dengan persamaan sebagai berikut:

a. $\mathrm{H}_{0}: \mathrm{P} \leq 50 \%$

$\mathrm{H \alpha}: \mathrm{P}>50 \%$

$\mathrm{H}_{0}$ : Diduga kurang dari atau sama dengan $50 \%$ petani di Kecamatan Srandakan memiliki respons yang tinggi dalam membudidayakan dan memanfaatkan sorgum di Kecamatan Srandakan Kabupaten Bantul. 
$\mathrm{H} \alpha$ : Diduga lebih dari $50 \%$ petani di Kecamatan Srandakan memiliki respons yang tinggi dalam membudidayakan sorgum dan memanfaatkan di Kecamatan Srandakan Kabupaten Bantul.

b. Tingkat signifikansi $0,1(90 \%), \mathrm{n}=30$

c. Statistik Pengujian :

$$
Z_{h i t}=\frac{\frac{x}{n}-p_{o}}{\sqrt{\frac{p_{o}\left(1-p_{o}\right)}{n}}}
$$

Dengan keterangan :

po : proporsi populasi $(50 \%)$

$\mathrm{x} \quad$ : jumlah sampel yang memiliki respons tinggi dalam budidaya sorgum.

$\mathrm{n} \quad$ : jumlah keseluruhan sampel

Kriteria pengujian

- $\quad$ Zhit $\geq$ Ztabel, Ho ditolak dan Ha diterima.

- $\quad$ Zhit $\leq$ Ztabel, Ho diterima dan Ha ditolak.

Pengujian hipotesis yang ketiga yaitu dengan analisis regresi linier berganda digunakan untuk mengetahui faktor-faktor yang mempengaruhi respons petani petani terhadap munculnya inovasi budidaya dan pemanfaatan sorgum. Rumus yang digunakan adalah

Sedangkan analisis regresi linier berganda digunakan dengan rumus:

$$
\begin{aligned}
Y= & A+b<X_{1}+b_{2} X_{2}+b_{3} X_{3}+b_{4} X 4+\ldots \ldots . . \\
& +b_{7} X_{7}
\end{aligned}
$$

Keterangan :

Y : Respons

A : Konstanta

b : Koefisien regresi

$\mathrm{X} 1$ : Umur

$\mathrm{X} 2$ : Tingkat pendidikan petani

$\mathrm{X} 3$ : Pengalaman bertani

$\mathrm{X} 4$ : Intensitas mengikuti penyuluhan

X5 : Persepsi

X6 : Motivasi

$\mathrm{X} 7$ : Luas lahan

Pengujian hipotesis :

Ho : b1 =b2=b3=b4=b5=b6=b7

po : proporsi populasi (50\%) $\mathrm{x} \quad$ : jumlah sampel yang memiliki respons tinggi dalam budidaya sorgum.

$\mathrm{n} \quad$ : jumlah keseluruhan sampel

Ha : $\mathrm{b} 1 \neq \mathrm{b} 2 \neq \mathrm{b} 3 \neq \mathrm{b} 4 \quad \mathrm{~b} 5 \neq \mathrm{b} 6 \neq \mathrm{b} 7$

Ho : Tidak ada pengaruh antara umur, tingkat pendidikan petani, pengalaman bertani, intensitas mengikuti penyuluhan, persepsi, motivasi, serta luas lahan.

$\mathrm{Ha}$ : Ada pengaruh antara umur, tingkat pendidikan petani, pengalaman bertani, intensitas mengikuti penyuluhan, persepsi, motivasi, serta luas lahan.

Kriteria pengujian:

Sig $\leq \alpha$ atau F hitung $\geq$ Ftabel maka Ho diterima dan Ha ditolak.

Sig $>\alpha$ atau $F$ hitung $<$ Ftabel maka Ho ditolak dan Ha diterima.

\section{HASIL PENELITIAN DAN PEMAHASAN}

Inovasi Budidaya dan Pemanfaatan Sorgum di Kabupaten Bantul

Kelompok Tani Bismo merupakan kelompok Tani yang secara terpadu membudidayakan tanaman pangan dan palawija di lahan produktif (sawah). Pada tahun 2011 muncul inovasi di Kelompok Tani Bismo yaitu budidaya sorgum dan pemanfaatannya. Inovasi budidaya dan pemanfaatan sorgum ini merupakan salah satu program dari kementrian dirjen sarana dan prasarana yang bekerjasama dengan Dinas Pertanian dan Kehutanan Kabupaten Bantul sebagai upaya pemanfaatan lahan marginal dan diversifikasi pangan.

Sebagai salah satu teknologi baru yang berkembang di Desa Poncosari, budidaya dan pemanfaatan sorgum mulai dikenalkan dari tahun 2011 kemudian berkembang secara terus menerus. Meskipun menjadi suatu inovasi, budidaya sorgum dapat dilakukan secara mudah oleh petani karena tahapannya yang tidak jauh berbeda dengan budidaya jagung. Sedangkan untuk pemanfaatan sorgum sendiri, menjadi teknologi baru yang diterapkan oleh petani karena pengolahannya yang belum pernah dilakukan sebelumnya.

Inovasi Budidaya dan Pemanfaatan Sorgumdari segi teknis budidaya di Desa Poncosari meliputi : 
a. Persiapan Lahan

Persiapan lahan dilakukan dengan mengolah tanah supaya dapat lebih produktif ditanami sorgum yaitu dengan mencangkul dengan intensitas 2-3 kali. Persiapan lahan dilakukan di lahan yang akan ditanami sorgum yaitu lahan sawah dan lahan bantaran sungai progo.

\section{b. Penanaman}

Penanaman dilakukan oleh petani dengan memberikan benih tanaman sorgum dengan jenis varietas sweet sorgum dengan intensitas masing- masing 2-3 biji perlubang. Dengan jarak tanam $20 \times 70 \mathrm{~cm}$. Penanaman dilakukan dengan cara ditugal kemudian diisi dengan biji pada masing-masing lubang kemudian dituutp dengan pupuk organik (kompos).

c. Pemeliharaan

1) Pengairan

Pengairan dilakukan sebanyak 3 kali dalam satu musim yaitu pada 15 hari setelah tanam, 35 hari setelah tanam, dan 60 hari setelah tanam.

1) Pemupukan

Pemupukan dilakukan dengan melakukan pemupukan pertama pada umur 15-20 hari setelah tanam dengan menggunakan Urea dan Phonska dengan intensitas masing-masing $200 \mathrm{~kg} / \mathrm{Ha}$. Pemupukan kedua dilakukan pada saat tanaman berumur 30-35 hari setelah tanam.

\section{d. Pemanenan dan Pasca Panen}

Pemanenan dilakukan setelah kurang lebih 3 bulan pumur sorgum atau 90 hari dengan disesuaikan tingkat kematangan. Pemanenan dilakukan dengan cara memotong pangkal tangkai/malai buah sorgum dengan panjang sekitar 40-60 cm. Kemudian dilakukan perontokan biji, dan pengeringan biji dengan waktu 20-2 jam. Kemudian biji yang sudah kering dimasukkan dalam karung dan disimpan digudang.

Inovasi sorgum dari segi pemanfaatan merupakan adanya teknologi baru dalam pemanfaatan sorgum misalnya menjadi produk lain seperti makanan (tempe, tahu, tepung, kue kering), alkohol (bahan obat), pakan ternak (fermentasi), bahan bakar. Kelompok Tani Bismo melakukan pemanfaatan sorgum menjadi produk lain, pakan ternak, dan alkohol. Pemanfaatan ini merupakan suatu pengembangan dari inovasi budidaya sorgum.

\section{Respons Petani terhadap Inovasi Budidaya dan Pemanfaatan Sorgum}

Secara keseluruhan respons petani yang meliputi komponen sikap dan perilaku berada pada kategori baik. Untuk mengetahui besarnya dominansi respons petani dari kedua komponen tersebut perlu dilakukan perbandingan dan jumlah keseluruhan untuk mngetahui besarnya tingkat respons secara keseluruhan terhadap Inovasi Budidaya dan Pemanfaatan Sorgumyang dikembangkan di Desa Poncosari. Tingkat respons secara keseluruhan petani terhadap inovasi budidaya dan pemanfaatan sorgum di Desa Poncosari dapat dilihat pada Tabel 6.3.

Tabel 6.3. Respons petani terhadap Inovasi Budidaya dan Pemanfaatan Sorgum di Desa Poncosari

\begin{tabular}{ccccr}
\hline No. & $\begin{array}{c}\text { Aspek } \\
\text { Respons }\end{array}$ & $\begin{array}{c}\text { Interval } \\
\text { Skor }\end{array}$ & $\begin{array}{c}\text { Skor } \\
\text { Rerata }\end{array}$ & $\begin{array}{c}\text { Tingkat } \\
\text { Respons (\%) }\end{array}$ \\
\hline 1 & Sikap & $0-63$ & 37,86 & 60,10 \\
2 & Perilaku & $0-42$ & 23,03 & 54,83 \\
\hline & Jumlah & $\mathbf{0 - 1 0 5}$ & $\mathbf{6 0 , 8 9}$ & $\mathbf{5 7 , 9 9}$ \\
\hline
\end{tabular}

Sumber : Analisis Data Primer, 2014

Berdasarkan Tabel 6.3 dapat diketahui bahwa tingkat respons petani terhadap pengembangan inovasi budidaya dan pemanfaatan sorgum sebesar $57,99 \%$. Respons yang positif dari petani terhadap inovasi budidaya dan pemanfaatan sorgum tergolong cukup baik. Hal ini menunjukkan bahwa petani memiliki pengetahuan, perasaan, kecenderungan, dan perilaku yang cukup baik terhadap adanya pengembangan inovasi sorgum di Desa Poncosari, Kecamatan Srandakan. Pengembangan sorgum dapat diterima dan diterapkan oleh petani. Meskipun demikian, masih perlu adanya peningkatan pengembangan sehingga manfaat dapat diperoleh oleh petani.

Dalam penelitian ini dibuat kategori respons diantarnya yaitu tidak mendukung (0-35), raguragu (36-70), dan mendukung (71-105). Hal ini digunakan untuk menentukan sebaran respons 
petani terhadap inovasi budidaya dan pemanfaatan sorgum di Desa Poncosari, Kecamatan Srandakan. Sebaran petani berdasarkan respon terhadap Inovasi Budidaya dan Pemanfaatan Sorgumdapat dilihat pada Tabel 6.4.

Tabel 6.4 Sebaran petani berdasarkan respon terhadap inovasi budidaya sorgum

\begin{tabular}{clcc}
\hline No & Kategori (Skor) & $\begin{array}{c}\text { Jumlah } \\
\text { (Jiwa) }\end{array}$ & $\begin{array}{c}\text { Persentase } \\
(\mathbf{\%})\end{array}$ \\
\hline 1 & Tidak mendukung (0-35) & 0 & 0.00 \\
2 & Ragu-ragu (36-70) & 27 & 90,00 \\
3 & Mendukung (71-105) & 3 & 10,00 \\
\hline Jumlah & 30 & 100,00 \\
\hline
\end{tabular}

Sumber : Analisis Data Primer, 2014

Berdasarkan Tabel 6.4. dapat diketahui bahwa sebagian besar petani ragu-ragu terhadap adanya inovasi budidaya dan pemanfaatan sorgum yaitu $90 \%$. Hal ini dikarenakan sifat dari teknologi yang masih baru bagi petani sehingga belum menunjukkan hasil yang nyata menyebabkan petani masih ragu untuk mengembangkannya lebih lanjut.

Dalam penelitian ini, hipotesis kedua adalah diduga lebih dari 50\% petani di Kecamatan Srandakan memiliki respons yang tinggi dalam membudidayakan sorgum di Kecamatan Srandakan Kabupaten Bantul. Untuk membuktikan kebenaran hipotesis kedua tersebut dilakukan uji proporsi sebagai berikut :

\footnotetext{
$Z_{\text {hit }}=\frac{\frac{x}{n}-p_{o}}{\text { Dengan keterangan }: \sqrt{\frac{p_{o}\left(1-p_{o}\right)}{n}}}$

po : proporsi populasi $(50 \%)$

$\mathrm{x} \quad$ : jumlah sampel yang memiliki respons tinggi dalam budidaya sorgum.

$\mathrm{n} \quad$ : jumlah keseluruhan sampel
}

\section{a. Hipotesis}

$\mathrm{H}_{0}$ : Diduga kurang dari atau sama dengan 50\% petani di Kecamatan Srandakan memiliki respons yang tinggi dalam membudidayakan dan memanfaatkan sorgum di Kecamatan Srandakan Kabupaten Bantul.

$\mathrm{H}_{\alpha}$ : Diduga lebih dari $50 \%$ petani di Kecamatan Srandakan memiliki respons yang tinggi dalam membudidayakan dan memanfaatkan sorgum di Kecamatan Srandakan Kabupaten Bantul.
1. Taraf signifikansi $0,1(10 \%), n=30, x=3$, Po $=50 \%$

$$
Z_{h i t}=\frac{\frac{x}{n}-p_{o}}{\sqrt{\frac{p_{o}\left(1-p_{o}\right)}{n}}}
$$

$$
\begin{aligned}
& Z_{\text {hit }}=\frac{\frac{3}{30}-0,5}{\sqrt{\frac{0,5(1-0,5)}{30}}} \\
& Z_{\text {hit }}=\frac{-0,40}{0,0912} \\
& Z_{\text {hit }}=-4,381
\end{aligned}
$$

\section{Kriteria Pengujian}

Ho diterima bila : $Z$ hitung $\leq$ Ztabel

Ho ditolak bila : Z hitung $>$ Ztabel

\section{Kesimpulan}

$$
\begin{array}{ll}
Z \text { hitung } & =-4,381 \\
\text { Ztabel } & =-1,282
\end{array}
$$

Berdasarkan hasil perhitungan menggunakan uji proporsi diperoleh nilai $Z$ hitung sebesar -4.381 dan nilai $Z$ tabel sebesar -1.282 . Hal ini berarti $\mathrm{Z}_{\text {hitung }}<\mathrm{Z}_{\text {tabel }}$, sehingga Ho diterima maka dapat disimpulkan bahwa kurang dari atau sama dengan $50 \%$ petani di Kecamatan Srandakan memiliki respons yang tinggi dalam membudidayakan dsn memanfaatkan sorgum di Kecamatan Srandakan Kabupaten Bantul.

\section{Faktor-faktor yang Mempengaruhi Respons Petani terhadap Inovasi Budidaya dan Pemanfatan Sorgumdi Kecamatan Srandakan}

Tujuan dari penelitian yang ketiga adalah mengetahui faktor-faktor yang mempengaruhi respons petani terhadap inovasi budidaya dan pemanfaatan sorgum di Kecamatan Srandakan, Kabupaten Bantul. Faktor- faktor yang diduga mempengaruhi respons petani terhadap inovasi budidaya dibedakan menjadi yaitu faktor internal dan faktor eksternal. Faktor internal terdiri dari umur, tingkat pendidikan, pengalaman usaha tani sorgum, persepsi, dan motivasi. Sedangkan faktor 
Tabel 6.5. Hasil Analisis Regresi Linier Berganda terhadap Faktor- Faktor yang Diduga Mempengaruhi Respons Petani terhadap Inovasi Budidaya dan Pemanfaatan Sorgum (Model 1)

\begin{tabular}{clcccc}
\hline No. & \multicolumn{1}{c}{ Variabel } & $\begin{array}{c}\text { Koefisien } \\
\text { Regresi (B) }\end{array}$ & t hitung & Sig & Ket \\
\hline 1 & Umur (X1) & $-0,070$ & $-0,838$ & 0,411 & NS \\
2 & Tingkat pendidikan (X2) & $-0,077$ & $-0,319$ & 0,752 & NS \\
3 & Pengalaman usaha tani sorgum (X3) & 1,469 & 0,569 & 0,575 & NS \\
4 & Persepsi petani (X4) & 1,373 & 3,406 & 0,003 & $*$ \\
5 & Motivasi petani (X5) & 0,319 & 3,102 & 0,005 & $*$ \\
6 & Intensitas mengikuti penyuluhan (X6) & $-0,620$ & $-1,348$ & 0,191 & NS \\
7 & Luas Lahan (X7) & $-4,361$ & $-0,749$ & 0,461 & NS \\
\hline Konstanta & 12,915 & & & \\
\hline R square & 0,747 & & & \\
Adjusted square & 0,666 & & & \\
$\quad$ Fhitung & 9,270 & & & \\
$\quad$ Ftabel & 2,010 & & & \\
\hline Keterangan : *signifikansi pada taraf 10\% & & & & \\
\hline
\end{tabular}

Sumber : Analisis Data Primer, 2014

eksternal terdiri dari luas lahan dan intensitas mengikuti penyuluhan.

Berdasarkan pengujian analisis regresi linier beganda, variabel dependen adalah respons petani terhadap inovasi budidaya dan pemanfaatan sorgum $(\mathrm{Y})$ dan variabel independen $(\mathrm{X})$ meliputi umur, tingkat pendidikan, pengalaman usaha tani sorgum, persepsi, motivasi, intensitas mengikuti penyuluhan, dan luas lahan. Hasil analisis regresi linier berganda terhadap faktor- faktor yang diduga mempengaruhi respons petani terhadap inovasi budidaya dan pemanfaatan sorgum dapat dilihat pada Tabel 6.5.

Tabel 6.5. menunjukkan model 1 yaitu tahap awal pada metode backward. Dalam tahap ini menampilkan seluruh faktor-faktor yang diduga mempengaruhi respons petani terhadap inovasi budidaya dan pemanfaatan sorgum. Berdasarkan Tabel 7.5. dapat dilihat bahwa terdapat dua variabel (X) yang berpengaruh terhdap respons petani (Y) dan lima variabel lainnya (X) tidak berpengaruh terhadap respons petani $(\mathrm{Y})$ dengan nilai signifikansi sebesar 10\% $(\alpha=0,1)$. Berikut hasil uji tiap- tiap variabel yang diduga mempengaruhi respons petani terhadap inovasi budidaya sorgum.

\section{a. $\operatorname{Umur}(\mathrm{X} 1)$}

Pada Tabel 6.5. variabel umur yang diketahui memiliki koefisien regresi sebesar $-0,070$ tidak berpengaruh nyata terhadap respon petani. Ini dibuktikan dengan nilai signifikansi sebesar 0,411 dimana nilai ini lebih besar daripada taraf signifikansi $\alpha=0,1$. Hal ini menunjukkan bahwa hipotesis semakin tua umur petani, semakin rendah respons petani terhadap inovasi budidaya dan pemanfaatan sorgum ditolak. Ini berarti semakin tidak produktif (tua) umur petani tidak mempengaruhi tingkat respons petani terhadap inovasi budidaya sorgum.

\section{b. Tingkat Pendidikan (X2)}

Berdasarkan Tabel 6.5 dapat diketahui memiliki koefisien regresi sebesar -0,077 dengan t hitung sebesar -0,319. Nilai signifikansi untuk variabel pendidikan sebesar 0,752 lebih besar daripada taraf signifikansi $\alpha=0,1$ menunjukkan bahwa variabel pendidikan tidak berpengaruh nyata terhadap respons petani dengan adanya inovasi budidaya sorgum. Sekaligus menjawab bahwa hipotesis semakin tinggi tingkat pendidikan petani, semakin tinggi respons petani terhadap inovasi budidaya dan pemanfaatan sorgum ditolak.

\section{c. Pengalaman Usaha Tani Sorgum (X3)}

Berdasarkan Tabel 6.5 dapat diketahui memiliki koefisien regresi sebesar 1,469 dengan t hitung sebesar 0,569. Nilai signifikansi untuk variabel pengalaman usaha tani sorgum sebesar 0,575 lebih besar daripada taraf signifikansi $\alpha=0,1$ menunjukkan bahwa variabel pengalaman usaha tani sorgum tidak berpengaruh nyata terhadap respons petani dengan adanya inovasi budidaya sorgum. Sekaligus menjawab bahwa hipotesis semakin lama pengalaman usaha tani sorgum petani, semakin 
tinggi respons petani terhadap inovasi budidaya dan pemanfaatan sorgum ditolak.

\section{d. Persepsi Petani (X4)}

Berdasarkan Tabel 6.5 dapat diketahui memiliki koefisien regresi sebesar 1,373 dengan t hitung sebesar 3,406. Nilai signifikansi untuk variabel pendidikan sebesar 0,003 lebih kecil daripada taraf signifikansi $\alpha=0,1$ menunjukkan bahwa variabel persepsi berpengaruh nyata terhadap respons petani dengan adanya inovasi budidaya sorgum. Sekaligus menjawab bahwa hipotesis semakin tinggi persepsi petani, semakin tinggi respons petani terhadap inovasi budidaya dan pemanfaatan sorgum diterima.

\section{e. Motivasi (X5)}

Berdasarkan Tabel 6.5 dapat diketahui memiliki koefisien regresi sebesar 0,319 dengan t hitung sebesar 3,102. Nilai signifikansi untuk variabel pendidikan sebesar 0,005 lebih kecil daripada taraf signifikansi $\alpha=0,1$ menunjukkan bahwa variabel motivasi berpengaruh nyata terhadap respons petani dengan adanya inovasi budidaya sorgum. Sekaligus menjawab bahwa hipotesis semakin tinggi motivasi petani, semakin tinggi respons petani terhadap inovasi budidaya dan pemanfaatan sorgum diterima.

\section{f. Intensitas Mengikuti Penyuluhan (X6)}

Berdasarkan Tabel 6.5 dapat diketahui memiliki koefisien regresi sebesar -0,620 dengan $\mathrm{t}$ hitung sebesar $-1,348$. Nilai signifikansi untuk variabel pengalaman usaha tani sorgum sebesar 0,191 lebih besar daripada taraf signifikansi $\alpha=0,1$ menunjukkan bahwa variabel intensitas mengikuti penyuluhan tidak berpengaruh nyata terhadap respons petani dengan adanya inovasi budidaya sorgum. Sekaligus menjawab bahwa hipotesis semakin semakin sering petani mengikuti penyuluhan, semakin tinggi respons petani terhadap inovasi budidaya dan pemanfaatan sorgum ditolak.

\section{g. Luas Lahan (X7)}

Berdasarkan Tabel 6.5 dapat diketahui memiliki koefisien regresi sebesar -4,361dengan t hitung sebesar $-0,749$. Nilai signifikansi untuk variabel pengalaman usaha tani sorgum sebesar 0,461 lebih besar daripada taraf signifikansi $\alpha=$ 0,1 menunjukkan bahwa variabel luas lahan tidak berpengaruh nyata terhadap respons petani dengan adanya inovasi budidaya sorgum. Sekaligus menjawab bahwa hipotesis semakin luas lahan petani, maka semakin tinggi respons petani dalam mengembangkan inovasi budidaya dan pemanfaatan sorgum ditolak.

Model 1 menunjukkan semua variabel independent dengan nilai signifikansi yang lebih besar maupun lebih kecil daripada taraf signifikansi $\alpha=0,1$. Artinya seluruh variabel independent baik yang berpengaruh maupun tidak berpengaruh terhadap variabel dependent muncul pada model 1. Kemudian satu demi satu variabel independent yang tidak berpengaruh dikeluarkan sampai pada model terakhir (model 6) dimana hanya terdapat dua variabel independent yang berpengaruh terhadap variabel dependent. Hasil analisis regresi linier brganda terhadap faktor-faktor yang diduga mempengaruhi respons petani terhadap inovasi budidaya dan pemanfaatan sorgum dengan metode backward (Model 6) dapat dilihat pada Tabel 6.6.

Berdasarkan Tabel 6.6 dapat diketahui bahwa nilai signifikansi dari variabel persepsi dan

Tabel 6.6. Hasil Analisis Regresi Linier Berganda terhadap Faktor- Faktor yang Diduga Mempengaruhi Respons Petani terhadap Inovasi Budidaya dan Pemanfaatan Sorgum (Model 6)

\begin{tabular}{clcccc}
\hline No. & \multicolumn{1}{c}{ Variabel } & $\begin{array}{c}\text { Koefisien } \\
\text { Regresi (B) }\end{array}$ & t hitung & Sig & \multirow{2}{*}{ Ket } \\
\hline 1 & Persepsi petani (X4) & 1,347 & 3,546 & 0,001 & $*$ \\
2 & Motivasi petani (X5) & 0,319 & 3,256 & 0,003 & $*$ \\
\hline Konstanta & 8,863 & & & \\
\hline & R square & 0,707 & & & \\
& Adjusted square & 0,686 & & & \\
& Fhitung & 32,518 & & & \\
& Ftabel & 2,91 & & & \\
\hline
\end{tabular}

Keterangan : *signifikansi pada taraf

kesalahan $10 \%(\alpha=0,1)$

Sumber : Analisis Data Primer, 2014 
variabel motivasi adalah 0,001 dan 0,003 . Nilai signifikansi dari kedua variabel yang lebih kecil daripada taraf signifikansi $\alpha=0,1$ membuktikan bahwa dua variabel tersebut berpengaruh nyata terhadap respons petani pada inovasi budidaya dan pemanfaatan sorgum di Kecamatan Srandakan, Kabupaten Bantul.

Nilai Adjusted square (koefisien determinasi) merupakan salah satu kriteria fungsi regresi yang menunjukkan cukup tepat atau tidak. Nilai Adjusted square antara 0-1 berarti semakin mendekati angka 1 maka model fungsi regresi semakin tepat. Berdasarkan Tabel 6.6 diketahui bahwa nilai Adjusted square sebesar 0,685 yang menunjukkan sebesar $68,5 \%$ respons petani terhadap inovasi budidaya dan pemanfaatan sorgum dipengaruhi oleh persepsi dan motivasi. Sedangkan sisanya sebesar 31,5\% dipengaruhi oleh variabel lain diluar model tersebut.

Nilai F merupakan perbandingan antara rerata kuadrat dari regresi dengan rerata kuadrat residu. Berdasarkan analisis, diperoleh nilai $\mathrm{F}$ hitung sebesar 32,518 dan F tabel sebesar 2, 91. Dengan nilai $\mathrm{F}$ hitung $>\mathrm{F}$ tabel menunjukkan bahwa variabel persepsi dan motivasi secara bersama-sama berpengaruh nyata terhadap respons petani terhadap inovasi budidaya sorgum.

Berdasarkan hasil analisis regresi linear berganda pada Tabel 6.6 diperoleh persamaan regresi sebagai berikut:

$$
\mathrm{Y}=8,863+1,347 \mathrm{X} 4+0,319 \mathrm{X} 5
$$

\section{Keterangan :}

$\mathrm{Y}=$ Respons petani terhadap inovasi budidaya sorgum
$\mathrm{X} 4=$ Persepsi petani

$\mathrm{X} 5$ = Motivasi petani

Berikut ini akan dibahas hasil uji hipotesis dari masing- masing faktor yang mempengaruhi respons petani terhadap inovasi budidaya dan pemanfaatan sorgum di Desa Poncosari, Kecamatan Srandakan, Kabupaten Bantul.

\section{a. Persepsi}

Hasil analisis regresi (model 6) menunjukkan bahwa nilai signifikansi vaariabel persepsi sebesar 0,001 lebih kecil daripada taraf signifikansi $\alpha=0,1$. Variabel persepsi mempunyai nilai t hitung sebesar 3, 546 dan nilai $t$ tabel sebesar 1, 699 sehingga $t$ hitung $>\mathrm{t}$ tabel yang berarti hipotesis diterima, persepsi petani berpengaruh nyata terhadap respons petani terhadap inovasi budidaya sorgum. Berdasarkan Tabel 6.6 diperoleh persamaan regresi sebagai berikut :

$$
Y=8,863+1,347 X 4
$$

Keterangan :

$\mathrm{Y}=$ Respons petani terhadap inovasi budidaya sorgum

$\mathrm{X} 4=$ Persepsi petani

Persamaan regresi linear pengaruh variabel persepsi teradap respons petani pada inovasi budidaya dan pemanfaatan sorgum apabila disajikan dalam bentuk grafik dengan asumsi variabel lainnya konstan dapat dilihat pada Gambar 6.1.

Dari Gambar 6.1 dapat dilihat bahwa koefisien regresi variabel persepsi petani berpengaruh positif

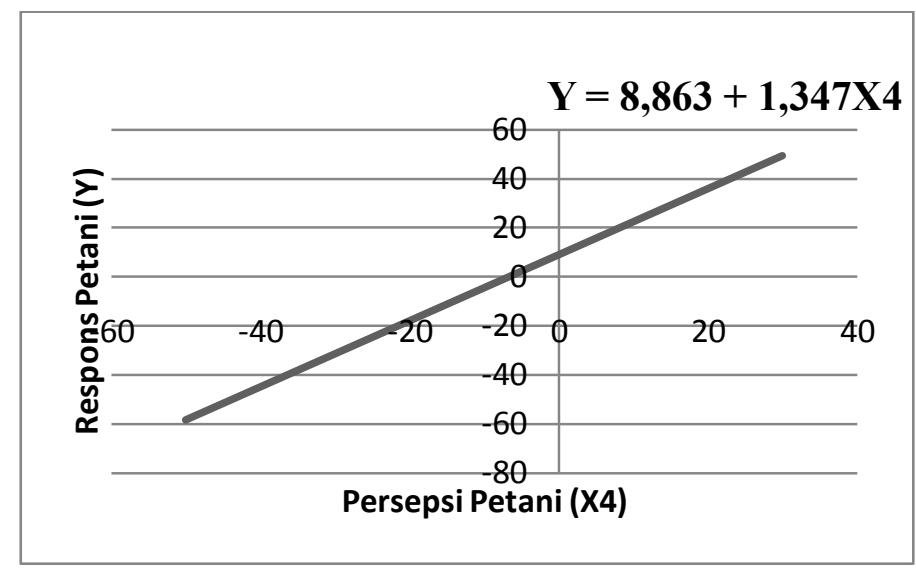

Gambar 6.1. Grafik Pengaruh Persepsi terhadap Respons Petani terhadap Inovasi Budidaya dan Pemanfaatan Sorgumdi Desa Poncosari, Kecamatan Srandakan, Kabupaten Bantul 
(+) terhadap respons petani terhadap inovasi budidaya dan pemanfaatan sorgum. Tanda positif $(+)$ pada koefisien regresi menunjukkan bahwa arah hubungan antara variabel persepsi petani dengan respons petani adalah searah. Ini berarti bahwa semakin baik persepsi petani mengenai inovasi budidaya dan pemanfaatan sorgum maka semakin tinggi respons petani terhadap inovasi budidaya sorgum. Nilai konstanta berdasarkan persamaan regresi diperoleh nilai sebesar 8,863 , apabila tidak ada pengaruh dari variabel persepsi petani $(\mathrm{X}=0)$ maka nilai dari respons petani sebesar 8,863 . Nilai koefisien regresi variabel persepsi sebesar 1,347 yang menunjukkan bahwa setiap penambahan satu satuan variabel persepsi dapat menaikkan variabel respons petani sebesar 1,347. Dengan demikian dapat disimpulkan bahwa hipotesis semakin baik persepsi petani maka semakin tinggi respons petani terhadap inovasi budidaya dan pemanfaatan sorgum diterima.

\section{b. Motivasi Petani}

Hasil analisis regresi (model 6) menunjukkan bahwa nilai signifikansi vaariabel motivasi sebesar 0,003 lebih kecil daripada taraf signifikansi $\alpha=0,1$. Variabel persepsi mempunyai nilai t hitung sebesar 3, 256 dan nilai $t$ tabel sebesar 1, 699 sehingga $t$ hitung $>\mathrm{t}$ tabel yang berarti hipotesis diterima, motivasi petani terhadap inovasi budidaya sorgum. Berdasarkan Tabel 6.6. diperoleh persamaan regresi sebagai berikut :

$$
Y=8,863+0,319 X 5
$$

Keterangan :

$\mathrm{Y}=$ Respons petani terhadap inovasi budidaya sorgum

$\mathrm{X} 5=$ Motivasi petani

Persamaan regresi linear pengaruh variabel motivasi teradap respons petani pada inovasi budidaya dan pemanfaatan sorgum apabila disajikan dalam bentuk grafik dengan asumsi variabel lainnya konstan dapat dilhat pada Gambar 6.2.

Dari Gambar 6.2 dapat dilihat bahwa koefisien regresi variabel motivasi petani berpengaruh positif $(+)$ terhadap respons petani terhadap inovasi budidaya sorgum. Tanda positif $(+)$ pada koefisien regresi menunjukkan bahwa arah hubungan antara variabel motivasi petani dengan respons petani adalah searah. Ini berarti bahwa semakin baik motivasi petani mengenai inovasi budidaya dan pemanfaatan sorgum maka semakin tinggi respons petani terhadap inovasi budidaya sorgum. Nilai konstanta berdasarkan persamaan regresi diperoleh nilai sebesar 8,863 , apabila tidak ada pengaruh dari variabel motivasi petani $(X=0)$ maka nilai dari respons petani sebesar 8,863 . Nilai koefisien regresi variabel motivasi sebesar 0,319 yang menunjukkan bahwa setiap penambahan satu satuan variabel motivasi dapat menaikkan variabel respons petani sebesar 0,319. Dengan demikian dapat disimpulkan bahwa hipotesis semakin tinggi motivasi petani maka semakin tinggi respons petani

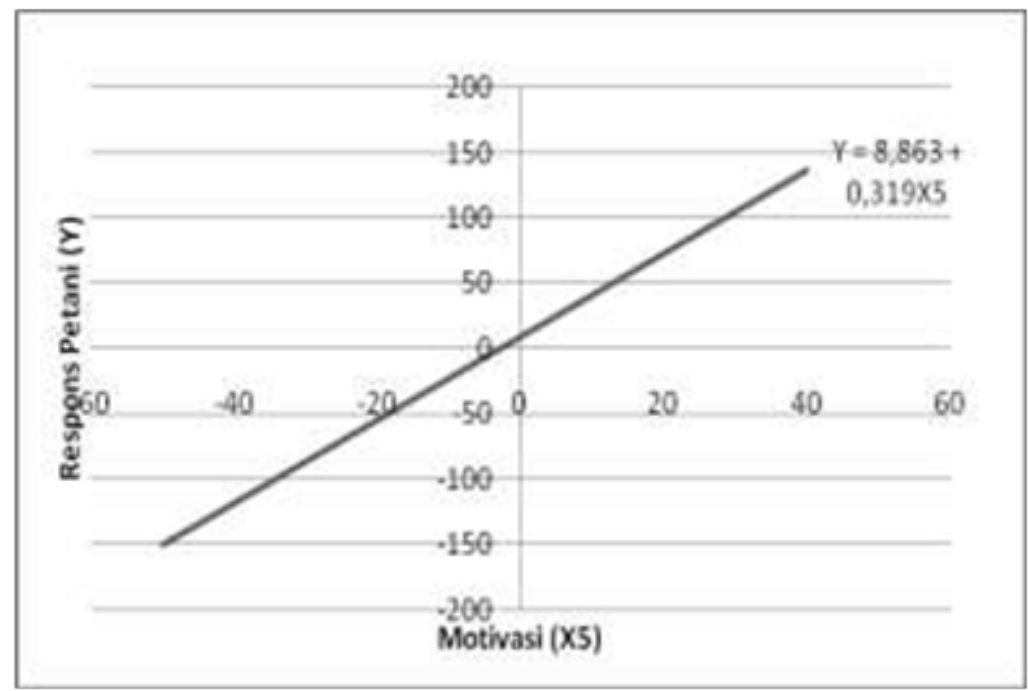

Gambar 6.2. Grafik Pengaruh Motivasi terhadap Respons Petani terhadap Inovasi Budidaya dan Pemanfaatan Sorgumdi Desa Poncosari, Kecamatan Srandakan, Kabupaten Bantul 
terhadap inovasi budidaya dan pemanfaatan sorgum diterima.

\section{KESIMPULAN}

1. Inovasi budidaya dan pemanfaatan sorgum dikembangkan di Kabupaten Bantul sebagai upaya optimalisasi lahan marginal dan penganekaragaman pangan sebagai salah satu usaha mengatasi kerawanan pangan yang diinisiasi oleh pemerintah Daerah melalui Dinas Pertanian dan Kehutanan Kabupaten Bantul.

2. Tingkat respons petani terhdap inovasi budidaya dan pemanfaatan sorgum sebesar $57,99 \%$. Dimana $90 \%$ petani masih ragu- ragu terhadap penerapan inovasi budidaya sorgum.

3. Faktor- faktor yang berpengaruh nyata secara positif terhadap respons petani terhadap inovasi budidaya dan pemanfaatan sorgum di Kecamatan Srandakan, Kabupaten Bantul adalah persepsi petani dan motivasi petani.

a. Semakin baik persepsi petani maka semakin tinggi respons petani

b. Semakin tinggi motivasi petani maka semakin tinggi respons petani

4. Faktor- faktor yang tidak berpengaruh nyata terhadap respons petani terhadap inovasi budidaya dan pemanfaatan sorgum adalah umur, tingkat pendidikan, luas lahan, pengalaman usaha tani sorgum, dan intensitas mengikuti penyuluhan.

\section{DAFTAR PUSTAKA}

Ahmadi, A. 2007. Psikologi Sosial. Rineka Cipta, Jakarta.

Asmawati, Desa. 2002. Psikologi Untuk Golongan Profesional. Universiti Kebangsaan Malaysia: Mc Graw-Hill. Malaysia.

Dayakisni, Tri Hudaniah. 2003. Psikologi sosial - buku 1. Universitas Muhammadiyah Malang. University Press malang.
Gerungan, W. A. 1978. Psikologi Sosial. Eresco, Bandung.

Gibson, J., L. Donnely., J. H. Ivancevich., M. john dan J. Wahid. 1988. Organisasi dan Manajemen: Perilaku Struktur Proses. Erlangga, Jakarta.

Hatta, G.M. 2012. Potensi Tanaman Sorgum Untuk Menopang Ketahanan Pangan Nasional.

$<$ http://ristek.go.id/index.php/module/N ews + News/id/12015>. Diakses pada 12 Oktober 2014.

Human, S. 2014. Riset dan Pengembangan Sorgum Dan Gandum untuk Ketahanan pangan. BATAN, Jakarta. < http://www.opi.lipi. go.id/data/1228964432/data/1308671032131 9802838.makalah.pdf>. Diakses pada 12 Okatober 2014.

Ismail, Inu. G. dan A. Kodir M. 1977. Cara Bercocok Tanam Sorgum. Lembaga Pusat Penelitian Pertanian, Bogor.

Mardikanto, T. 1993. Penyuluhan Pembangunan Pertanian. Sebelas Maret University Press, Surakarta

Maslow, A.H. 1993. Motivasi dan Kepribadian 1. Teori Motivasi dengan Pendekata Hirarki Kebutuhan Manusia. PT remaja Rosdakarya Offset, Bandung.

Risaptono, 1980. Respons Petani terhadap penggunaan traktor pada usaha tani padai sawah di Kabupaten Indramayu Jawa Barat. Fakultas Pertanian. Universitas Gadjah Mada. Skripsi.

Rismunandar, dan F.H. Fraeyhoven. 1973.Sorgum Tanaman Serba Guna. N. V Masa Baru, Bandung.

Van Den Ban, A. W dan Hawkins, H. S. 1999. Penyuluh Pertanian. Penerbit Kanisius, Yogyakarta.

Wibowo, Rudi. 2000. Pertanian dan Pangan Bunga Rampai Pemikiran Menuju Ketahanan Pangan. Sinar Harapan, Jakarta. 